\title{
Glucose Metabolism in Xanthomonas campestris
}

\author{
By C. WHITFIELD, ${ }^{\dagger} \uparrow$ I. W. SUTHERLAND ${ }^{1 *}$ AND R. E. CRIPPS ${ }^{2}$ \\ ${ }^{1}$ Department of Microbiology, University of Edinburgh, West Mains Road, \\ Edinburgh EH9 3JG, U.K. \\ ${ }^{2}$ Shell Research Ltd, Shell Biosciences Laboratory, Sittingbourne Research Centre, \\ Sittingbourne, Kent ME9 8AG, U.K.
}

(Received 10 September 1981)

\begin{abstract}
The pathways of glucose metabolism in Xanthomonas campestris closely resemble those described for Pseudomonas aeruginosa, in which two discrete systems exist for the uptake of glucose, one periplasmic and oxidative requiring glucose dehydrogenase activity, the second intracellular and phosphorylative. These systems lead to the production of 6phosphogluconate, which may be metabolized via the Entner-Doudoroff pathway and the pentose phosphate pathway. Terminal oxidation is mediated by the tricarboxylic acid cycle. A mucoid strain of $X$. campestris lacked glucose dehydrogenase activity and thus the oxidative pathway was not functional; the pentose phosphate pathway was also inoperative in this strain, as evidenced by the absence of 6-phosphogluconate dehydrogenase activity. Nonmucoid mutants appeared identical to the parent strain; however, a second group of mutants (crenated mutants) were derepressed for both glucose dehydrogenase and 6phosphogluconate dehydrogenase. Gluconate kinase was not detected in any of the $X$. campestris strains studied when grown on glucose; however, growth of the parent strain on gluconate resulted in the induction of this enzyme.
\end{abstract}

\section{INTRODUCTION}

Katznelson $(1955,1957)$ studied the metabolism of gluconate by Xanthomonas species; although sonic lysates of $X$. campestris and $X$. pruni (but not $X$. phaseoli) were active, intact cells were not capable of metabolizing gluconate. Employing radiorespirometric techniques, Zagallo \& Wang (1967) showed that most glucose $(80-90 \%)$ was catabolized via the Entner-Doudoroff pathway, with the pentose phosphate pathway fulfilling a minor role in several Xanthomonas species. These reports suggest a possible similarity to the glucose metabolizing system of Pseudomonas aeruginosa ( $\mathrm{Ng} \&$ Dawes, 1973) which possesses two coupled, yet discrete, pathways (Fig. 1). The oxidative pathway, operating in the periplasm, with a characteristically high $K_{\mathrm{m}}$ for glucose and an absolute requirement for glucose dehydrogenase activity (Midgley \& Dawes, 1973), is linked to an intracellular phosphorylative pathway by a transport system with a low $K_{\mathrm{m}}$ for glucose and a broad specificity. Subsequent metabolism occurs via the pentose phosphate and Entner-Doudoroff pathways and terminal oxidation.

We now report preliminary data concerning glucose metabolism in a series of $X$. campestris mutants selected for alterations in surface polysaccharides (Whitfield et al., 1981).

\footnotetext{
$\dagger$ Present address: Department of Biology, University of Calgary, Calgary, Canada.
} 


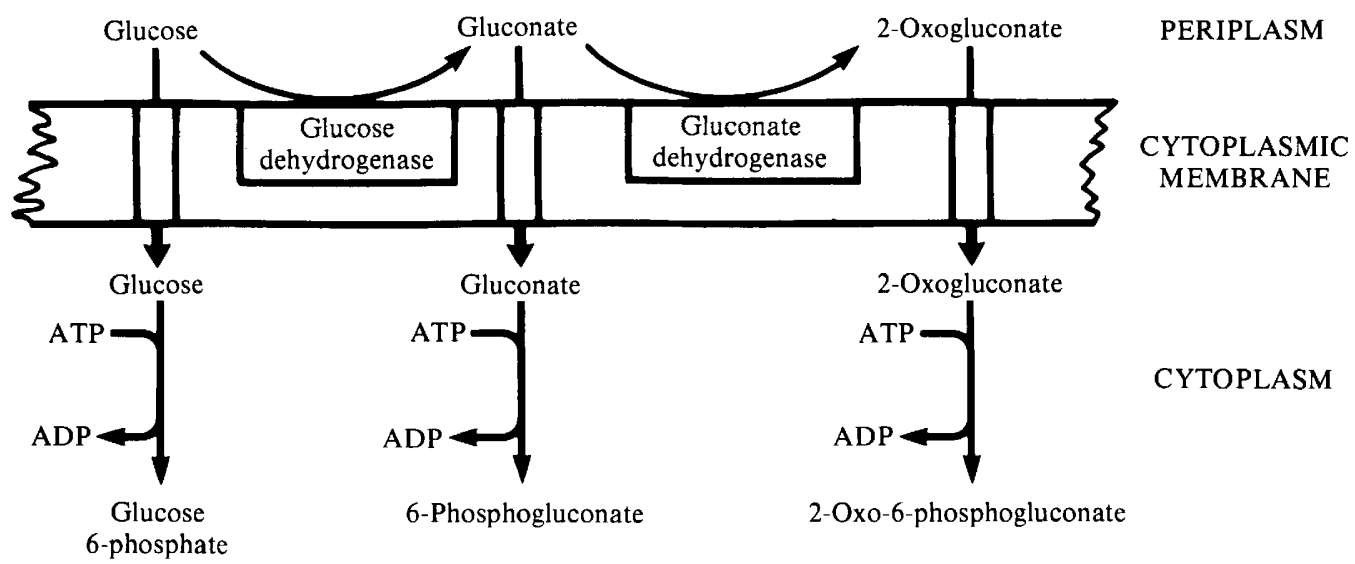

Fig. 1. Pathways of glucose catabolism and related transport systems in Pseudomonas aeruginosa.

\section{METHODS}

Growth of bacteria. The bacterial strains and cultural conditions have been described elsewhere (Whitfield et al., 1981).

Preparation of cell-free extracts. Bacteria were harvested in mid- to late-exponential phase and washed twice in $67 \mathrm{~mm}$-sodium phosphate buffer, $\mathrm{pH} 7.0$ and in $120 \mathrm{~mm}$-glycyl-glycine buffer, $\mathrm{pH} \mathrm{7.0.} \mathrm{They} \mathrm{were} \mathrm{then}$ resuspended in $60 \mathrm{~mm}$-glycyl-glycine buffer, $\mathrm{pH} 7.0$ and disrupted by sonication. Debris was removed by centrifuging at $7000 \mathrm{~g}$ for $15 \mathrm{~min}$; the supernatant was used as a crude cell extract.

Enzyme assays. All enzymes were assayed in freshly prepared extracts at $30^{\circ} \mathrm{C}$ under optimal conditions of $\mathrm{pH}$, substrate and cofactor concentration. Measurements were made in a Gilford model 240 spectrophotometer. Reaction mixtures, in cuvettes of $1 \mathrm{~cm}$ path length contained a final volume of $1 \mathrm{ml}$. Specific activities are expressed as $\mu \mathrm{mol}$ substrate converted (mg protein) $)^{-1} \mathrm{~min}^{-1}$. Reproducibility of the assays was within $\pm 10 \%$. The assumed $\varepsilon_{340}$ for NADPH was $6.22 \times 10^{3}$ litre $\mathrm{mol}^{-1} \mathrm{~cm}^{-1}$ and $\varepsilon_{600}$ for dichlorophenol indophenol was $19.5 \times 10^{3}$ litre $\mathrm{mol}^{-1} \mathrm{~cm}^{-1}$ at pH 6.6 and $9.1 \times 10^{3}$ litre $\mathrm{mol}^{-1} \mathrm{~cm}^{-1}$ at $\mathrm{pH} 5.5(\mathrm{Ng} \&$ Dawes, 1973).

The following enzymes were assayed according to the methods of $\mathrm{Ng} \&$ Dawes (1973): hexokinase (EC 2.7.1.1); glucokinase (EC 2.7.1.12); glucose-6-phosphate dehydrogenase (EC 1.1.1.49); 6-phosphogluconate dehydrogenase (decarboxylating 6-phospho-D-gluconate: NADP ${ }^{+}$oxidoreductase) (EC 1.1.1.44); isocitrate dehydrogenase (EC 1.1.1.42); glucose dehydrogenase (EC 1.1.1.47); gluconate dehydrogenase (EC 1.1.99.3); 6-phosphogluconate dehydratase (EC 4.2.1.12) and 3-deoxy-2-oxo-6-phosphogluconate aldolase (EC 4.1.2.14) (Entner-Doudoroff enzymes); aconitase (EC 4.2.1.3). 2-Oxogluconate kinase (EC 2.7.1.13) and 2-oxogluconate-6-phosphate reductase (oxogluconate-metabolizing enzymes) were assayed as described by Roberts et al. (1973). Phosphofructokinase was detected by the method of Racker (1947).

Protein was estimated by the Lowry method.

Gluconate was detected by paper chromatography with butan-1-ol/pyridine/water $(6: 4: 3$, by vol.) as solvent (Whistler \& Conrad, 1954). Portions of culture filtrate were lyophilized before chromatographic comparison with authentic gluconic acid.

Biochemicals. All chemicals, of the purest grade available, were obtained from BDH. Biochemicals and enzymes were from Boehringer, and $\mathrm{D}-\left[\mathrm{U}^{-14} \mathrm{C}\right] \mathrm{glucose}\left(230 \mathrm{mCi} \mu \mathrm{mol}^{-1}\right), \mathrm{D}-\left[\mathrm{U}^{14}{ }^{14}\right.$ lgalactose $\left(50-200 \mathrm{mCi} \mu \mathrm{mol}^{-1}\right)$ and D- $\left[\mathrm{U}^{-14} \mathrm{C}\right]$ mannose $\left(2-5 \mathrm{mCi} \mu \mathrm{mol}^{-1}\right)$ were from Amersham $(1 \mathrm{mCi}=37 \mathrm{MBq})$.

\section{RESULTS}

Growth of $X$. campestris was accompanied by a marked decrease in the $\mathrm{pH}$ of the medium; the decrease was greater in cultures of the crenated strains $646 \mathrm{D}, 646 \mathrm{E}$ and $646 \mathrm{KR}$ than in the wild type. On plates of bromothymol blue/glucose medium, a colour change indicated acid production. Under identical conditions, growth of $X$. campestris $\mathrm{T} 646$ and non-mucoid mutants $646 \mathrm{NM} 1$ and $646 \mathrm{NM} 2$ did not induce a colour change. Following growth of crenated strains in glucose minimal medium, gluconate was detected in the culture filtrates. 
Table 1. Specific activities of glucose-metabolizing enzymes of Xanthomonas campestris strains

Cells were grown in 1-litre batch cultures containing minimal medium supplemented with D-glucose unless otherwise indicated; all carbon sources were at $2 \%(\mathrm{w} / \mathrm{v})$. The values given are the average of two determinations.

\begin{tabular}{|c|c|c|c|c|c|c|c|c|c|}
\hline \multirow[b]{3}{*}{ Enzyme } & \multicolumn{9}{|c|}{ Specific activity $\left[\mu \mathrm{mol} \min ^{-1}(\mathrm{mg} \text { protein })^{-1}\right]$} \\
\hline & \multicolumn{6}{|c|}{ Strains grown on glucose: } & \multicolumn{3}{|c|}{ T646 grown on: } \\
\hline & T646 & 646NM1 & $646 \mathrm{NM} 2$ & $646 \mathrm{D}$ & $646 \mathrm{E}$ & $646 \mathrm{KR}$ & Gluconate & Citrate & Glycerol \\
\hline $\begin{array}{l}\text { Glucose } \\
\text { dehydrogenase }\end{array}$ & ND & ND & ND & $10 \cdot 7$ & $7 \cdot 8$ & $4 \cdot 6$ & ND & ND & ND \\
\hline Hexokinase & $23 \cdot 0$ & $37 \cdot 3$ & $21 \cdot 3$ & $17 \cdot 9$ & $21 \cdot 3$ & $4 \cdot 6$ & $26 \cdot 3$ & $20 \cdot 3$ & $16 \cdot 1$ \\
\hline $\begin{array}{l}\text { Glucose-6- } \\
\text { phosphate } \\
\text { dehydrogenase }\end{array}$ & 144 & 253 & 252 & 129 & 116 & 107 & 153 & $77 \cdot 6$ & 114 \\
\hline Gluconate kinase & ND & ND & ND & ND & ND & ND & $8 \cdot 3$ & ND & ND \\
\hline $\begin{array}{l}\text { 6-Phospho- } \\
\text { gluconate } \\
\text { dehydrogenase }\end{array}$ & ND & ND & ND & 112 & 118 & 265 & ND & ND & ND \\
\hline $\begin{array}{l}\text { Gluconate } \\
\text { dehydrogenase }\end{array}$ & $6 \cdot 1$ & $5 \cdot 1$ & $7 \cdot 3$ & 11.4 & $10 \cdot 9$ & $11 \cdot 6$ & $15 \cdot 3$ & $4 \cdot 2$ & ND \\
\hline $\begin{array}{l}\text { 2-Oxogluconate } \\
\text { metabolizing } \\
\text { enzymes* }\end{array}$ & $14 \cdot 3$ & $16 \cdot 9$ & $38 \cdot 3$ & $40 \cdot 2$ & $56 \cdot 1$ & $41 \cdot 3$ & $19 \cdot 1$ & 6.4 & $4 \cdot 9$ \\
\hline $\begin{array}{l}\text { Entner- } \\
\text { Doudoroff } \\
\text { enzymes } †\end{array}$ & 11.4 & $7 \cdot 8$ & $6 \cdot 3$ & $14 \cdot 5$ & $12 \cdot 1$ & $7 \cdot 7$ & $6 \cdot 6$ & $5 \cdot 5$ & $11 \cdot 5$ \\
\hline Aconitase & 119 & $88 \cdot 5$ & $52 \cdot 6$ & $46 \cdot 2$ & $43 \cdot 7$ & $40 \cdot 2$ & 140 & $55 \cdot 2$ & $83 \cdot 1$ \\
\hline Isocitrate & 245 & 231 & 290 & 231 & 221 & 210 & 128 & 115 & $77 \cdot 3$ \\
\hline
\end{tabular}

ND, Not detected.

* 2-Oxogluconate kinase + 2-oxogluconate reductase.

† 6-Phosphogluconate dehydratase + 2-oxo-3-deoxygluconate aldolase.

No 2-oxogluconate was found. Crenated mutants and, to a lesser extent, strains T646, $646 \mathrm{NM} 1$ and $646 \mathrm{NM} 2$, grew in media containing gluconate or 2-oxogluconate as sole carbon source. This indirect evidence suggested that an oxidative pathway similar to that described for P. aeruginosa (Ng \& Dawes, 1973; Roberts et al., 1973) (Fig. 1) may function in the crenated $X$. campestris strains.

The activities of enzymes potentially involved in glucose metabolism by $X$. campestris strains were measured in cell lysates (Table 1). The enzymes tested were representative of the oxidative, phosphorylative and oxidative pentose phosphate pathways; isocitrate dehydrogenase and aconitase were measured to monitor tricarboxylic acid cycle activity. Differences in enzyme activity were apparent between the wild-type organism and mutants derived from it. Neither $X$. campestris T646 nor its non-mucoid mutants possessed detectable amounts of glucose dehydrogenase activity under the assay conditions used, whereas activity of this enzyme was present in extracts from crenated bacteria. Furthermore, gluconate dehydrogenase activity was higher in crenated strains than in wild-type bacteria. Enzymes responsible for the metabolism of 2-oxogluconate were detected in all strains examined.

Although the enzymes of the phosphorylative pathway were detected in all the strains studied, the activities of hexokinase and glucose-6-phosphate dehydrogenase varied.

Enzymes of the Entner-Doudoroff pathway were assayed in cell-free extracts by measuring pyruvate production using lactate dehydrogenase. Each strain studied produced pyruvate. No glycolysis occurred in these strains, since no phosphofructokinase activity was detected. The validity of the enzyme assay was verified with extracts of Escherichia coli. 
Extracts prepared from crenated mutants of $X$. campestris had detectable activity of 6-phosphogluconate dehydrogenase, a key enzyme of the oxidative pentose phosphate pathway. No activity of this enzyme was detected in extracts prepared from $X$. campestris T646 or non-mucoid bacteria. Since the assay depends upon the conversion of $\mathrm{NADP}^{+}$into NADPH, absolute values of enzyme activity should be regarded with caution. In a study of carbohydrate catabolism in mutant strains of $P$. aeruginosa (Blevins et al., 1975), increased 6-phosphogluconate dehydrogenase activity was detected only in those strains containing elevated levels of Entner-Doudoroff enzymes. The generation of glyceraldehyde 3-phosphate by this pathway may provide substrate for endogenous glyceraldehyde-3-phosphate dehydrogenase, thus creating errors in the assay. This problem was not found in the present study as values for the specific activity of 6-phosphogluconate dehydrogenase in crenated mutants were high, whereas no activity was detected in either parent or non-mucoid bacteria. The variations in amounts of Entner-Doudoroff enzymes should not account for the observed differences. All strains tested showed variable amounts of the representative enzymes of the tricarboxylic acid cycle.

Enzymes were also assayed in extracts from $X$. campestris $\mathrm{T} 646$ cells grown in minimal medium with different carbon sources (Table 1). No glucose dehydrogenase activity was detected. Growth on gluconate resulted in a fourfold increase in the activity of gluconate dehydrogenase when compared with values from glucose-grown cells; glucokinase activity was also present. The activity of 2-oxogluconate metabolizing enzymes was also higher in gluconate-grown cells. Growth on citrate resulted in a decrease in the specific activity of gluconate dehydrogenase, and no activity was detected in glycerol-grown bacteria. Activities of 2-oxogluconate metabolizing enzymes were lower in cells grown on either glycerol or citrate. The activities of glucose-6-phosphate dehydrogenase and, to a lesser extent, hexokinase were higher in extracts prepared from glucose- and gluconate-grown cells than in extracts of cells grown in glycerol or citrate media. The activity of enzymes of the Entner-Doudoroff pathway varied with growth substrate. Neither 6-phosphogluconate dehydrogenase nor phosphofructokinase activity was detected in any of these extracts. The activity of tricarboxylic acid enzymes was decreased in bacteria grown in media containing citrate and glycerol.

\section{DIS CUSSION}

Estimation of the amounts of glucose-metabolizing enzymes demonstrated differences between the $X$. campestris strains investigated. Crenated mutants appear to have higher specific activities of the enzymes involved in the oxidation of glucose to gluconate and subsequently to 2-oxogluconate. Operation of this essentially periplasmic system (see Fig. 1) may account for the observed decrease in $\mathrm{pH}$ of the medium during growth and the presence of gluconate after growth on glucose. Wild-type $X$. campestris T646 grew on gluconate but, unlike the crenated bacteria, grew only poorly on 2-oxogluconate. The apparent lack of glucose dehydrogenase activity in the wild-type and non-mucoid bacteria precludes operation of the periplasmic oxidative pathway. The ability to grow on gluconate, and the synthesis of detectable gluconokinase and gluconate dehydrogenase suggests that the defect in the periplasmic pathway does indeed lie at the glucose dehydrogenase step.

Although these results are in accord with those expected from an extracellular system analogous to that described in $P$. aeruginosa (Fig. 1), we have not attempted to describe the membrane location or orientation of the enzymes with regard to the periplasmic space in $X$. campestris.

Xanthomonas campestris strains possess the enzymes necessary for the intracellular phosphorylative pathway. Thus, these bacteria resemble $P$. aeruginos $a$ in the possession of two coupled, yet discrete, systems for glucose uptake and subsequent metabolism, although it is apparent that both systems operate only in the crenated mutants and not in either the 
parent or non-mucoid strains. In $P$. aeruginosa, the intracellular pathway is inhibited by the presence of high concentrations of gluconate produced periplasmically. Since $X$. campestris T646 lacks glucose dehydrogenase activity, such inhibition would not occur during growth on glucose. In $P$. aeruginosa, the presence of two pathways may perform a regulatory function since, under carbon-limiting conditions, $P$. aeruginosa transports glucose and metabolizes it via the intracellular pathway (Whiting et al., 1973).

Growth of $P$. aeruginosa on organic acids (e.g. citric, succinic) repressed enzymes of glucose metabolism (Hamilton \& Dawes, 1960; Hamlin et al., 1967). This occurs to a slight extent in $X$. campestris T646. Growth of $P$. aeruginosa on glycerol derepressed enzymes of glucose metabolism (Hamlin et al., 1967); this did not happen in $X$. campestris.

The inability of $X$. campestris to utilize the glycolytic pathway results from the lack of active phosphofructokinase, confirming results from $X$. phaseoli (Hochster \& Katznelson, 1958).

C. W. acknowledges receipt of an SRC CASE award.

\section{REFERENCES}

Blevins, W. T., Feary, T. W. \& Phibbs, P. V. (1975). 6-Phosphogluconate dehydratase deficiency in pleiotropic carbohydrate negative mutant strains of Pseudomonas aeruginosa. Journal of Bacteriology 121, 942-949.

Hamilton, W. A. \& Dawes, E. A. (1960). The nature of the diauxic effect with glucose and organic acids in Pseudomonas aeruginosa. Biochemical Journal 76, 70P.

Hamlin, B. T., Ng, F. M.-W. \& Dawes, E. A. (1967). Regulation of enzymes of glucose metabolism in Pseudomonas aeruginosa by citrate. In Microbial Physiology and Continuous Culture, pp. 211-231. London: H.M.S.O.

HochsteR, R. M. \& Katznelson, H. (1958). On the mechanism of glucose-6-phosphate oxidation in cell-free extracts of Xanthomonas phaseoli. Canadian Journal of Biochemistry and Physiology 36, 669-689.

KAtZNELSON, H. (1955). The metabolism of phytopathogenic bacteria. I. Comparative studies of the metabolism of representative species. Journal of Bacteriology 70, 469-475.

KATZNELSON, H. (1957). The metabolism of phytopathogenic bacteria. II. Metabolism of carbohydrates by cell-free extracts. Journal of Bacteriology 75, 540-543.

Midgley, M. \& Dawes, E. A. (1973). The regulation of transport of glucose and methylglucoside in Pseudomonas aeruginosa. Biochemical Journal 132, 141-154.
NG, F. M.-W. \& Dawes, E. A. (1973). Chemostat studies on the regulation of glucose metabolism in Pseudomonas aeruginosa. Biochemical Journal 132. 129-140.

RACKER, E. (1947). Spectrophotometric measurement of hexokinase and phosphohexokinase activity. Journal of Biological Chemistry 167, 843-854.

Roberts, B. K., Midgley, M. \& Dawes, E. A. (1973). The metabolism of 2-oxogluconate by Pseudomonas aeruginosa. Journal of General Microbiology 78, 319-329.

Whistler, R. L. \& ConRad, H. E. (1954). 2$O$-(D-galactopyranosyluronic acid)-L-rhamnose from okra mucilage. Journal of the American Chemical Society 76, 3544-3546.

Whitfield, C., Sutherland, I. W. \& Cripps, R. (1981). Surface polysaccharides in mutants of Xanthomonas campestris. Journal of General Microbiology 124, 385-392.

Whiting, P. H., Midgley, M. \& Dawes, E. A. (1976). The role of glucose limitation in the regulation of the transport of glucose, gluconate and 2-oxogluconate and of glucose metabolism in Pseudomonas aeruginosa. Journal of General Microbiology 92, 304-310.

ZAGallo, A. C. \& W ANG, C. H. (1967). Comparative glucose catabolism of Xanthomonas species. Journal of Bacteriology 93, 970-974. 